\title{
MENURUNKAN PRILAKU MEMBOLOS DENGAN LAYANAN KONSELING INDIVIDU MELALUI TEKNIK LATIHAN ASERTIF PADA SISWA KELAS XI TKJ 2 SMK RADEN PAKU WRINGINANOM
}

\author{
IDA TRISNAWATI \\ SMK Raden Paku Wringinanom \\ Idatrisnawati267@gmail.com
}

\begin{abstract}
Learning activities can be carried out if all components are met, namely teachers and students. In this modern era, truant behavior still occurs, especially students who do not have a stand, only join friends to skip class. The purpose of this classroom action research is the extent to which truancy behavior can be reduced with individual counseling through assertive training techniques to refuse invitations to truancy friends. The research subjects were students of class XI TKJ 2 SMK Raden Paku Wringinom for the 2020/2021 school year. The methods used in collecting data were questionnaires, interviews and observations. The results obtained in the first cycle were still low, namely $55 \%$ of the success indicator, while the second cycle experienced a success rate of $87.5 \%$. So it can be concluded that with assertive training students are firm in rejecting an invitation to truancy.
\end{abstract}

\section{ABSTRAK}

Kegiatan pembelajaran dapat terlaksana bila semua komponen terpenuhi, yaitu guru dan siswa. Di era modern seperti ini prilaku membolos masih terjadi, apalagi siswa yang tidak mempunyai pendirian hanya ikut-ikut teman untuk membolos masih saja terjadi. Tujuan dari penelitian tindlkan kelas ini adalah sejauh mana prilaku membolos dapat diturunkan dengan konseling individu melalui teknik latihan asertif untuk menolak ajakan teman membolos. Subjek penelitian adalah siswa kelas XI TKJ 2 SMK Raden Paku Wringinanom tahun ajaran 2020/2021. Metode yang digunakan dalam mengumpulkan data adalah angket, wawancara dan observasi. Hasil yang diperoleh pada siklus I masih rendah yaitu $55 \%$ dari indikator kebeerhasilan sedangkan disiklus II mengalami tingkat keberhasilan menjadi $87,5 \%$. Sehingga dapat disimpulkan bahwa dengan latihan asertif siswa bersikap tegas menolak ajakan teman membolos.

Cara mengutip: Trisnawati, I. (2020). Menurunkan Prilaku Membolos Dengan Layanan Konseling Individu Melalui Teknik Latihan Asertif Pada Siswa Kelas XI TKJ 2 SMK Raden Paku Wringinanom. Nusantara of Research : Jurnal Hasil-Hasil Penelitian Universitas Nusantara PGRI Kediri (e-Journal), 7(2), 86-91. https://doi.org/10.29407/nor.v7i2.15059

\section{PENDAHULUAN}

Proses pembelajaran di sekolah adalah kegiatan berkesinambungan antara guru dan siswa atau peserta didik. Belajar di sekolah dapat diimplementasikan apabila stimulus yang diberikan oleh guru dan respon yang ditangkap oleh peserta didik. Apabila hal tersebut tidak terlaksana, maka implementasi proses belajar dan mengajar tidak akan terjadi. Di era modern saat ini, perilaku membolos (ditching) menjadi fenomenal. Hal tersebut dikarenakan keterbatasan kuota dan alat yang digunakan pada saat proses belajar, bahkan tidak mempunya uang untuk membeli paket data. 
Gunarsa (2006:31), berpendapat bahwa perilaku membolos adalah tidak datang ke sekolah tanpa pengetahuan dari pihak sekolah. Sedangkan menurut Supriyo (2008:111), perilaku membolos dapat diartikan sebagai anak yang meninggalkan sekolah dan anak yang meningalkan sekolah sebelum usai. Pendapat lain dikemukakan oleh Kartini dan Kartono (2003:21) perilaku membolos merupakan prilaku yang melanggar norma-norma social sebagai akibat dari proses pengkondisian lingkungan yang buruk.

Fenomana membolos ini juga terjadi di sekolah peneliti. Berdasarkan need assessmen yang dilakukan oleh peneliti sebagai guru BK pada hari rabu tanggal 14 Oktober 2020 melalui google formulir dapat diketahui bahwa 60\% siswa membolos selama pembelajaran daring ini masih tinggi. Faktor penyebab membolos bermacam-macam. Dari hasil angket tersebut diperoleh data bahwa $20 \%$ siswa membolos karena tidak punya kuota internet, $40 \%$ siswa membolos karena diajak teman untuk nongkrong diwarung, 22\% tidur malas untuk pembelajran daring, $18 \%$ lebih asyik game online dari pada mengikuti pembelajaran daring. Sedangkan hasil observasi dan wawancara dengan wali kelas dan guru mata pelajaran yang dilaksanakan pada hari senin tanggal 12 September 2020 didapatkan data bahwa siswa yang sering tidak mengikuti pembelajaran jarak jauh sehingga mereka tidak mengerjakan tugas yang telah diberikan oleh guru.

Jika perilaku membolos seperti yang dikemukakan di atas dibiarkan dan tidak ditanggulangi dengan segera tentu akan membawa kerugian bagi anak anak yang bersangkutan serta orang tuanya sendiri. Kerugian nyata yang akan dialami anak adalah menurunnya prestasi belajar karena jarang mengikuti pelajaran. Pada akhirnya anak yang bersangkutan tidak naik kelas bahkan kemungkinan bisa berakibat fatal yaitu tidak dapat mengikuti pelajaran untuk seterusnya dan dinyatakan dikeluarkan dari sekolah. Oleh itu disini peneliti ingin melakukan konseling individu dengan menerapkan teknik latihan asertif pada siswa agar bisa menolak dengan tegas ajakan teman dan berkata tidak untuk membolos. Pemilihan strategi konseling individu oleh peneliti dikarenan peneliti bermaksud menggali informasi yang lebih mendalam lagi, dalam kegiatan konseling individu nantinya akan dilakukan dengan Teknik latihan asertif, dengan tujuan siswa mampu menolak ajakan temanya untuk membolos. Menurut Prayitno (2004) konseling individu merupakan layanan konseling yang dilakukan oleh seorang konselor terhadap seorang klien dalam rangka pengentasan masalah pribadi klien dalam suasana tatap muka dilaksanakan interaksi secara langsung antara klien dan konselor dalam rangka mambahas berbagai hal tentang masalah yang dialami klien. Konseling individu itu sendiri memiliki beberapa macam pendekatan yang dapat digunakan untuk membantu menyelesaikan permasalahan yang sedang dihadapi oleh siswa. Salah satu pendekatan konseling yang dapat digunakan dalam mengatasi masalah tersebut adalah konseling behavior. George dan Christiani (dalam Latipun, 2008) mengemukakan bahwa konseling behavior itu memilki ciri-ciri sebagai berikut: a) Berfokus pada perilaku yang tampak dan spesifik, b) Memerlukan kecermatan dalam perumusan tujuan terapeutik, c) Mengembangkan prosedur perlakuan spesifik sesuai dengan masalah klien, d) Penaksiran objektif atas tujuan terapeutik. Selain itu menurut Hartono (2012:129) Latihan asertif merupakan bentuk terapi perilaku yang dirancang untuk memberikan pelatihan ketegasan. 
Penelitian yang relevan juga dilakukan oleh Devi Marwati (2019) meneliti bahwa konseling kelompok dengan Teknik assertive training dapat mempengaruhi perilaku membolos siswa. Hasil yang didapat ada perbedaan tingkat membolos siswa sebelum mendapat layanan dan sesudah mendapat layanan. Berdasarkan latar belakang di atas peneliti sebagai guru BK di sekolah ingin menurunkan prilaku membolos siswa dengan konseling individu melalui Teknik latihan asertif. Tujuan dari penelitian ini untuk menurunkan perilaku membolos dengan Latihan asertif.

\section{METODE}

Model penelitian yang peneliti gunakan adalah Model Lewin (dalam Arikunto, 2004) komponennya adalah 1) Perencanaan (Planning), dalam tahap ini peneliti menjelaskan tentang apa, mengapa, kapan, dimana, oleh siapa dan bagaimana tindakan tersebut dilakukan. 2) Pelaksanaan (Actuating). Pelaksanaan yang merupakan implementasi atau penerapan isi rancangan. 3) Pengamatan (observing), kegiatan observasi dilakukan untuk mengamati aktifitas anak dan guru selama proses layanan berlangsung. 4) Perenungan (Reflecting), Merumuskan hal-hal yang belum dan telah dilakukan berdasarkan hasil observasi dan evaluasi.

Menurut Sugiyono (2017:81) sampel adalah bagian dari jumlah dan karakteristik yang dimiliki oleh populasi. Sampel dilakukan karena peneliti memiliki keterbatasan penelitian baik dari segi tenaga, waktu dan jumlah populasi. Oleh karena itu peneliti mengambil sampel yang benar-benar dapat mewakili. Sampel dari penelitian ini adalah salah satu siswa kelas XI TKJ 2 SMK Raden Paku Wringinanom, dimana terdapat satu siswa yang tingkat membolosnya paling tinggi diantara temannya. Penyebab siswa tersebut membolos adalah dia tidak bisa menolak ajakan temannya untuk bersantai diwarung. Siswa tadi pun tidak pernah mengumpulkan tugas dari guru mata pelajaran sehingga perlu tindak lanjut khusus. Waktu penelitian ini diiadakan pada tanggal 14 oktober 2020 sampai 30 Oktober 2020.

Teknik pengumpulan data menurut Sugiyono (2017:137) bila dilihat dari sumbernya ada dua yaitu primer dan sekunder. Data primer merupakan data yang diperoleh secara langsung sedangkan data sekunder merupakan data yang diperoleh dari pihak lain secara tidak langsung. Teknik pengumpulan data yang digunakan peneliti adalah angket, observasi dan wawancara. Angket digunakan untuk mengukur sejauh mana perilaku membolos siswa sebelum dan sesudah diberikan terapi perilaku. Observasi dilakukan pada saat pemberian layanan konseling maupun setelah siswa tersebut menerapkan latihan asertif. Wawancara digunakan untuk mengetahui perilaku siswa di setiap pembelajaran. Wawancara dalam penelitian ini melibatkan guru mata pelajaran.

Teknik pengolahan data yang digunakn peneliti adalah kualitatif dengan proses reduksi data, paparan data sampai penyimpulan. Menurut miles dan Huberman (1992:19), ada tiga tahapan yang harus dikerjakan dalam menganalisis data kualitatif, yaitu: reduksi data (data reduction), paparan data (data display), dan penarikan kesimpulan dan verifikasi (conclusion drawing/verifying). Analisa data kualitatif dilakukan secara bersamaan dengan proses pengumpulan data berlangsung dan sesudah pengumpulan data. Data hasil pengamatan guru sejawat yang berkolaborasi disederhanakan dalam bentuk tabel, dinarasikan dan disimpulkan. 
Hasil kesimpulan ini dipergunakan untuk memperbaiki penelitian pada siklus berikutnya. Reduksi data diperoleh dari hasil wawancara dan observasi serta dokumentasi pelaksanaan konseling, dengan merangkum dan memfokuskan pada tujuan penelitian. Selanjutnya, data hasil proses reduksi disajikan dalam bentuk catatan agar peneliti dapat menganalisa dengan mudah dalam bentuk refleksi dan disajikan dalam bentuk teks. Hasil dari reduksi data dan penyajian data disimpulkan untuk menjawab rumusan masalah yang ingin diungkap.

\section{HASIL}

Berdasarkan hasil pengumpulan data dari wawancara guru mata pelajaran didapat data bahwa siswa Tgr (inisial) kelas XI TKJ 2 memiliki tingkat membolos tinggi diantara temannya yang lain. Yaitu 3-4 kali dalam seminggu. Perilaku membolos tersebut disebabkan karena siswa tidak dapat menolak ajakan teman dengan tegas untuk tidak membolos. Dia sudah berusaha menolak tapi selalu tidak berhasil.

Indikator perilaku membolos siswa disini adalah: 1) siswa malas mengikuti pembelajaran, 2) siswa ikut-ikutan teman membolos, 3) tidak masuk kembali setelah meminta izin, 4) tidak mengumpulkan tugas, dan 5) sering tidak mengikuti pembelajaran. Dari indikator tesebut dibuat item angket untuk mengukur tingkat membolos siswa. Dari ini juga dibuatkan kriteria tingkat membolos.

Berdasarkan hasil pemberian layanan konseling individu pada siklus I diperoleh hasil bahwa: a) siswa belum bisa memahami tujuan dari pemberian layanan, b) siswa belum bisa menerapkan latihan asertif yang diberikan oleh guru, c) siswa masih ragu-ragu dalam mengatakan tidak untuk membolos. Karena tujuan dari penelitian ini belum tercapai maka dilakukan siklus II. Di siklus II ini siswa sudah ada kemajuan, sudah bisa memerankan strategi latihan asertif dan mampu bermain peran dengan peneliti, sehingga dia mampu menolak ajakan temannya dan perilaku membolos dapat diturunkan. Data yang diperoleh peneliti dari prasiklus, siklus I dan siklus II adalah sebagai berikut:

Tabel 1. kategori tingkat membolos siswa

\begin{tabular}{cc}
\hline Kategori & Skor \\
\hline Rendah & $5-35$ \\
Sedang & $36-65$ \\
Tinggi & $66-95$ \\
\hline
\end{tabular}

Tabel 2. tingkat membolos siswa pra siklus, siklus I dan siklus II

\begin{tabular}{cccc}
\hline Nama & Keterangan & Skor & Kategori \\
\hline Tgr & Pra siklus & 87 & Tinggi \\
Tgr & Siklus I & 55 & Sedang \\
Tgr & Siklus II & 32 & Rendah \\
\hline
\end{tabular}




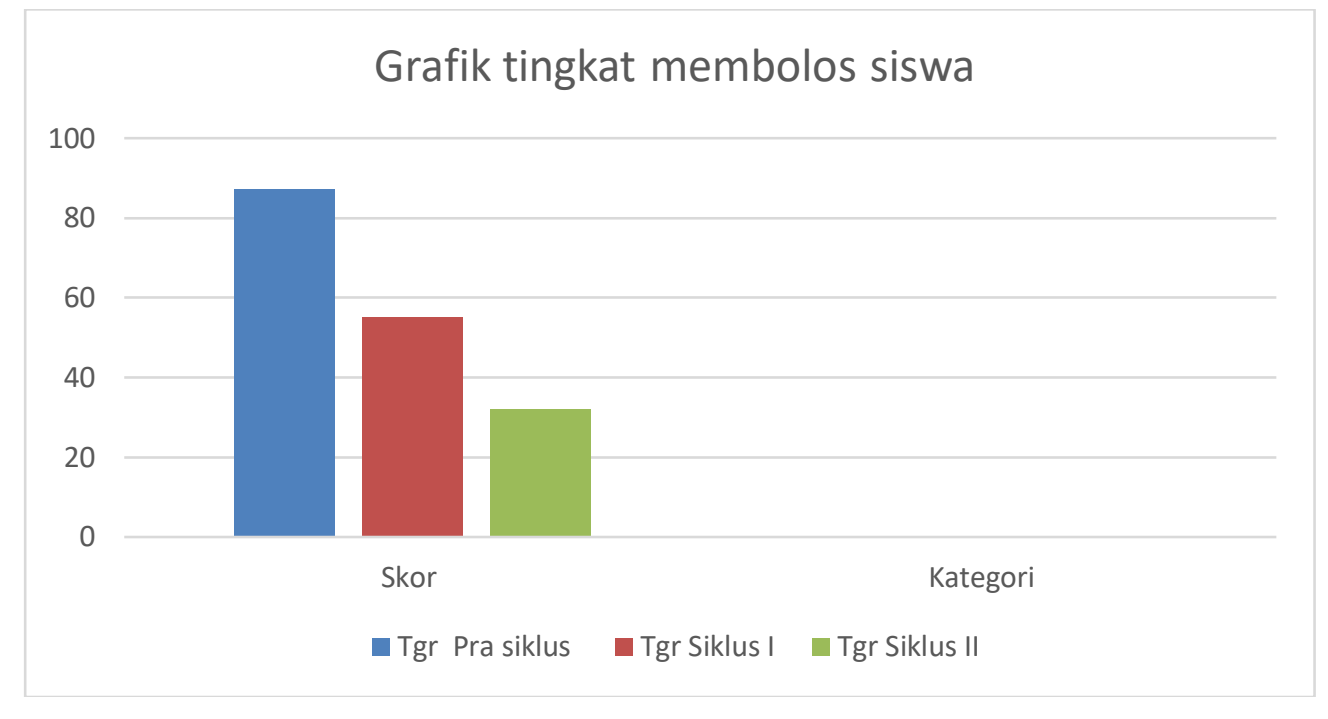

Gambar 1. Grafik tingkat membolos siswa

\section{PEMBAHASAN}

Dari hasil observasi dalam pelaksanaan konseling individu untuk menurunkan perilaku membolos siswa menggunakan Teknik latihan asertif sudah mencapai hasil yang maksimal. Dari evaluasi hasil yang diperoleh Siswa sudah semangat dalam mengikuti pembelajaran, siswa sudah mengumpulkan tugas dengan tepat waktu, dan sudah tidak terpengaruh temannya untuk membolos lagi. Tingkat membolos siswajuga mengalami penurunan.

Data yang diperoleh pada siklus I masih terdapat beberapa kendala yang dihadapi siswa dalam mempraktekkan latihan asertif. Siswa masih ragu-ragu untuk menolak ajakan teman atau berkata tidak untuk membolos. Dalam siklus I kategori tingkat membolos siswa masih sedang yaitu diangka $55 \%$ ynag berarti ini perlu diturunkan lagi. sehingga siswa dalam pemberian layanan konseling individu ini perlu diberikan treatment untuk perbaikan disiklus II

Hasil layanan konseling individu pada siklus II ini mengalami perbaikan, yaitu siswa sudah bisa berkata tidak untuk membolos, sudah bisa menolak ajakan teman dan mampu mempraktekkan latihan asertif sehingga diperoleh data tingkat membolos siswa mengalami penurunan di angka 32\%. Hal ini sesuai dengan tujuan penelitian yaitu siswa mampu mengatakan tidak untuk membolos sehingga perilaku membolos bisa menurun. Data tersebut juga didukung dengan gambaran grafik data yang menunjukan perubahan yang cukup signifikan dan bagus dari siswa tersebut. Dari hasil tersebut dapat dikatakan penggunaan konseling individu dengan Teknik Lathan asertif sangat efektif untuk menurunkan prilaku membolos pada siswa.

\section{KESIMPULAN DAN SARAN}

Dari hasil uraian pemaparan dan pembahasan data di atas, maka peneliti dapat menyimpulkan bahwa prilaku membolos dapat diturunkan dengan memberikan layanan konseling individu melalui teknik latihan asertif untuk bisa menolak dengan tegas ajakan teman membolos ataupun berkata tidak untuk membolos. Hasil dari penelitian ini tentunya masih jauh dari kata sempurna, maka dari itu peneliti memberi saran untuk semua pihak supaya terus 
mengembangkan keprofesionalan sebagai guru BK dan selalu mengupdet kemampuan dalam menerapkan berbagai teori dan strategi dalam proses konseling untuk membantu siswa dalam menyelesaikan permasalahan yang dihadapi.

\section{DAFTAR RUJUKAN}

Arikunto, Suharsimi. 2014. Prosedur Penelitian Suatu Pendekatan Praktek. Jakarta: Rineka Cipta

Arikunto, Suharsimi 2004. Dasar-Dasar Evaluasi Pendidikan. Jakarta: Bumi Aksara.

Erman Amti, Prayitno. 2013. Dasar-Dasar Bimbingan dan Konseling. Jakarta: Rineka Cipta.

Gunarsa, Singgih. D. 2012. Psikologi Untuk Membimbing. Jakarta: Gunung Mulia.

Hartono, dkk. 2018. Psikologi Konseling, Jakarta: Kencana.

Kartono, Kartini. 1995. Psikologi Umum. Bandung: Mandar Maju.

Latipun. (2008). Psikologi Konseling. Malang: UPT UMM.

Marwati, Devi. 2019. Pengaruh Layanan Konseling Kelompok Dengan Teknik Latihan Asertif Terhadap Prilaku Membolos Peserta Didik SMK 4 Bandar Lampung. Skripsi. Lampung: Universitas Islam Negeri Raden Intan.

Miles, B. Mathew dan Michael Huberman. 1992. Analisis Data Kualitatif Buku Sumber Tentang Metode-metode Baru. Jakarta: UIP.

Nyoman Yoga Aruna,Ni Ketut Suarni,Ni Nengah Madri Antari. 2014. Efektivitas Konseling Behavioral Teknik Assertive Training Untuk Meminimalisasi Perilaku Menyimpang Pada Siswa Kelas Viii Smp Negeri 2 Singaraja Tahun Pelajaran 2013/2014. EJournal Undiksa Jurusan Bimbingan Konseling,Volume: 2 No 1.

Prayitno. (2004). Layanan Konseling Perorangan. Padang : Universitas Negeri Padang Press.

Selfi. 2017. Penerapan Teknik Assertive Training dalam Mereduksi Konformitas Negatif Terhadap Kelompok Sebaya di SM. Journal of EST, Volume 3 Nomor 2.

Sugiyono. (2017). Metode Penelitian Kuantitatif, Kualitatif, dan R\&D. Bandung : Alfabeta, CV.

Supriyo. 2008. Studi Kasus Bimbingan Konseling. Semarang : CV.Nieuw Setapak

Susilo, H., dkk. 2009. Penelitian Tindakan Kelas. Malang: Bayumedia. 